\title{
Landslide susceptibility analyses in flysch areas in the north-eastern part of the Adriatic coast
}

\author{
S. Dugonjić Jovančević ${ }^{1}, \check{Z}$. Arbanas ${ }^{1}, \check{C}$. Benac ${ }^{1}$ \\ \& S. Mihalić Arbanas ${ }^{2}$ \\ ${ }^{1}$ University of Rijeka, Faculty of Civil Engineering, Croatia \\ ${ }^{2}$ University of Zagreb, Faculty of Mining, Geology and \\ Petroleum Engineering, Croatia
}

\begin{abstract}
Many different instability phenomena were found on flysch slopes in the past 30 years in the area of dominant geomorphological unit Rječina Valley - Sušačka Draga Valley - Bakar Bay - Vinodol Valley. This paper gives the review of present landslide appearances and the estimation of the possible landslide occurrence at the NW part of Vinodol Bakarac Valley, between the Bakarac and Križišće settlements, in the Kvarner area (north-eastern Croatian Adriatic coast). Based on longtime investigation work results for different purposes it was established that the wings and the base of the valley are made of flysch rock complex, consisting mainly of silty marl, laminated siltstones and fine grained sandstones near the contacts with karstified carbonate rock mass. Landslide susceptibility analysis of this area was made based on existing data about lithological composition and geological fabric, geotechnical properties of slope deposits and flysch bedrock, hydrological and hydrogeological conditions and existing landslides inventory map. Spatial analysis of unfavorable conditions in the investigated location resulted in landslide susceptibility map which divides the area into four classes of susceptibility.

Keywords: landslide susceptibility, flysch, Adriatic coast.
\end{abstract}

\section{Introduction}

Landslides are geomorphological processes associated with soil composition and material structure, tectonic, seismic, hydrogeological, climate and vegetation conditions in which they appear. Their appearances are a consequence of 
complex geological and hydrogeological conditions and loadings which act on the slope. Hazard assessment requires understanding of spatial and time variation of the threatening processes. The most of today's used landslide hazard analyses are based on the assumption that the similar past sliding conditions will cause similar landslide appearances in the future ("past and present are keys to the future") $[1,2]$. There is a great confusion between terms landslide susceptibility and landslide hazard in the existing literature. They are often used as synonyms, but in fact they are two different concepts of the analyses. Landslide susceptibility implies that landslide will appear in some area based on the local terrain conditions [3]. Hence it is a degree in which some area is subject to instability occurrence and does not suppose the temporal variability or the landslide magnitude. Landslide hazard, on the other hand, implies that landslide of a certain magnitude will appear in a certain time period on a certain area [4]. Landslide susceptibility analysis is only a component of landslide hazard analysis. Both concepts of the analysis have experienced huge development in the last few decades, but in spite of that, there is still no unique terminology used in different countries, and maps which are results of these analyses are of different quality, reliability and accuracy. The assessment of the landslide susceptibility and landslide hazard can either be based on the assessment of an expert (qualitative methodology), or the spatial distribution of past landslides can statistically be connected to the parameters which have influence the sliding (quantitative methodology) [5].

Geographic Information System (GIS) is a very powerful tool used in gathering, storing, processing, analysing and presenting the spatial data, working with different data base in the framework of all kinds of researches. It has lately become an important tool in landslide analyses. Landslide susceptibility, hazard or risk maps gained through the GIS analyses are much more accurate and effective, and give better results than the handmade maps gained from the same input data. The main restrictions of this technology are the suitable quality of the input data, high price of the digitalisation etc. The usual data set used in the analyses includes existing landslides, geology, geomorphology, land use, but it can also include the data about performed boreholes, soil parameters, ground water condition, rainfalls and all kinds of different parameters. From the digital terrain model (DTM) it is possible to get different sets of new data, like slope angle, orientation, water flows etc. Using different analyses function it is possible to combine some of these factor maps and to get the new results shown as a new map [6].

The north-western part of the Vinodol Valley in Croatia, located between settlements Bakarac, near the coast of Bakar Bay, and the neck near the Križišće village, was chosen for the analysis of landslide susceptibility. This is part of dominant geomorphological unit which strikes the direction: Rječina River Valley - Sušačka Draga Valley - Bakar Bay - Vinodol Valley. Many different types of instability phenomena, especially at the contact between flysch and carbonate rocky complex were found in this area [7]. Due to the multiple geological and geotechnical investigation works in this area performed earlier for different purposes (landslide investigations, investigations for highway and 
railway, etc.), there is a considerable amount of existing data about geological structure, geodynamic processes and geotechnical properties of the soil in the area.

\section{Geological properties and regional distribution of flysch deposits in north-eastern Adriatic zone}

The term flysch is used for the lithologically heterogeneous complex of clastic sediment rocks. The composition of the flysch complex is in gradual exchange of fine grained sediment deposits, such as shales, silts, marls and sandstones, but it can contain breccias, conglomerates and limestone rocks as well [8]. Regarding the different lithological structure, flysch rock mass has different physical and mechanical properties. If the flysch rock mass has been exposed to water and air, it is strongly affected by chemical weathering and decomposition, with leaching of soluble minerals $\mathrm{CaCO}_{3}$, oxidation and swelling. These processes cause changes in the physical and mechanical properties. Mechanical weathering also influences the chemical weathering of flysch components [9]. Fine-grained fractions, such as siltstones, are the most affected by chemical weathering. As a result of these processes, the volume of some fine grained flysch rock mass components increases over the time, and disintegrating processes transform these components in silts or clays. Through this gradual degradation, the physical and mechanical properties of clayey silt materials become more like engineering soil. A consequence of these types of geomorphological processes is a sporadic accumulation of eroded Quaternary deposits on the slopes that can be susceptible to sliding [8-10]. In a typical situation, the flysch bedrock is covered by these Quaternary deposits, except the isolated areas where the erosion is more expressed. In most cases the sliding surface is formed at the contact of the bedrock and the cover, which considering the structure of the slope, can vary between the residual soil (RS) and completely weathered flysch rock mass (CW) [10].

The outcrops of marls and siltstones from flysch rock mass are also visible in relatively wide area in Istrian Peninsula. This is Pazin Paleogene basin or so called "Gray Istria" stretching from Trieste Bay in the west to Učka Mountain in the east In the Kvarner area carbonate rocks prevail, whereas siliciclastic rock mass (marls and siltstones) are restricted (Fig. 1). Marls with significant $\mathrm{CaCO}_{3}$ component are lower part of Paleogene siliciclastic sedimentary rocks. Flysch rock mass (siltstones, marls, sandstones with intercalations of conglomerates and limestones) is situated in upper part of sediment basin [11].

Significant tectonic movements in analysed area occurred before Palaeogene. Similar compression tectonic stress (WNW-ESE) influenced also the areas of Istria and Kvarner. Further geodynamic evolution was subdivided in two main time-defined phases: a) from Eocene to Pliocene, and b) from Upper Pliocene to Present. The first one is characterized by progress of deformational processes caused by the influence of the regional principal stress oriented NE-SW. This phase started with formation of wide basins where sedimentation of clastic deposits (marls and flysch) occurred and finished with strong orogenic 


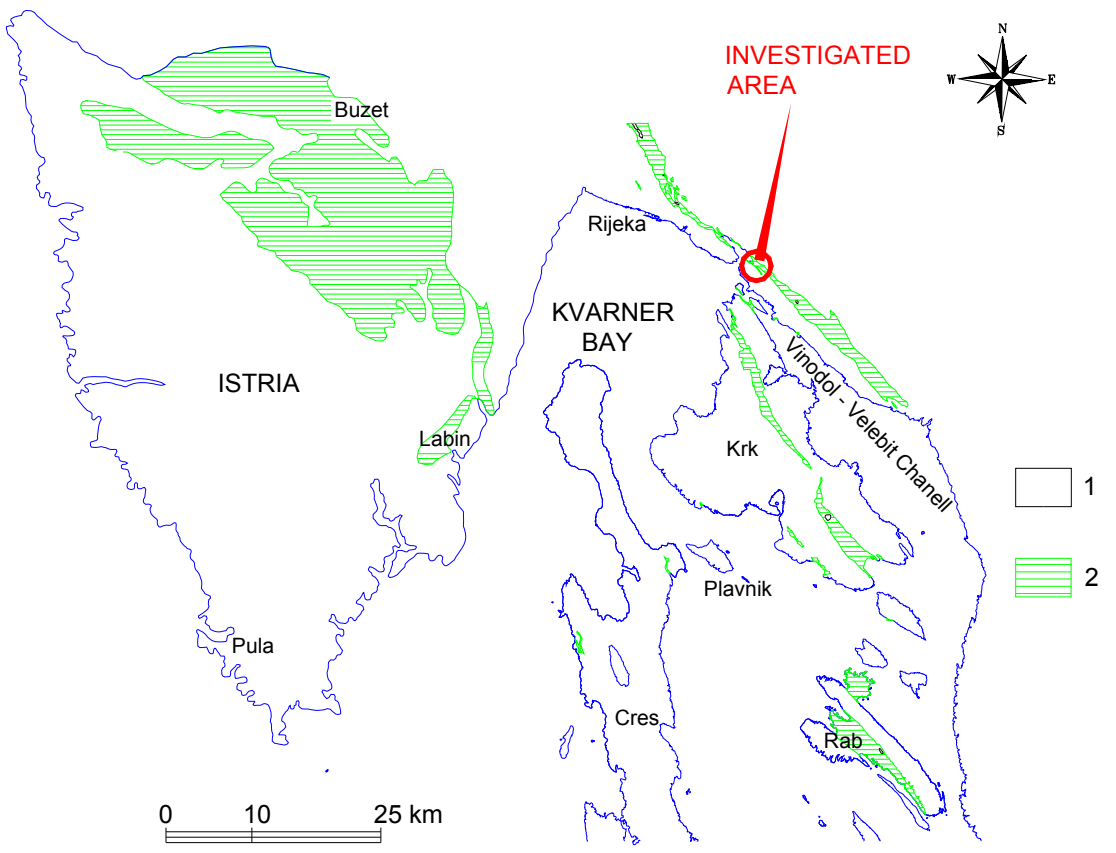

Figure 1: $\quad$ Simplified geological map of Istria and Kvarner area: 1- carbonate rock mass, 2- Paleogene flysch (according to [14]).

movements that formed the Dinarides. The structures formed in this phase have "Dinaric" strike (NW-SE) [12]. The second time-defined phase started in Upper Pliocene and is still active with the direction of regional principal stress N-S. Most often these movements reactivated already existing structures with Dinaric strike in the Kvarner area, but they also made their own structures with new strike orientation from East to West (E-W) [13]).

The tectonic structure that includes the studied part of the Vinodol Valley is part of a dominant morphostructural unit which strikes in the direction of the Rječina River Valley- Sušačka Draga Valley - Bakar Bay - Vinodol Valley [14] (Fig. 1). This geologic structure could be considered as a flysch syncline limited by faults, analogous with the tectonic type of the Vinodol Valley [15].

The kinematics of the structural elements of this part of the Vinodol Valley is based on the relationship between the relatively rigid carbonate rocks and relatively ductile siliciclastic rocks during simultaneous deformation [16]. The Cretaceous and the Palaeogene limestones are situated on the top of the slopes, while the Palaeogene siliciclastic rocks or flysch are located on the lower part of slopes, including the bottom of the valley (Figs. 3 and 4). The flysch rock complex is a block squeezed between the limestone rock complex to the northeast $(\mathrm{N}-\mathrm{E})$ and south-west $(\mathrm{S}-\mathrm{W})$. The effects of deformations are most distinctive at the contact between these two rock complexes. This explains why the relatively rigid limestone rock mass is pushed into a more ductile siliciclastic 
rock. On this way, a former straight line tectonic contact becomes the present toothed appearance $[15,17]$.

The analysed part of the Vinodol Valley between the Bakarac and the Križišće Village has an uneven morphology. The valley has asymmetrical cross section with wider north-eastern slope. The bottom of the valley is elevated from coast to south-eastern side up to $90 \mathrm{~m}$ a.s.l. The peaks reach the height of $300 \mathrm{~m}$ in the south-western and $350 \mathrm{~m}$ a.s.l. in the north-eastern part of the valley (Figs 2 and 3).

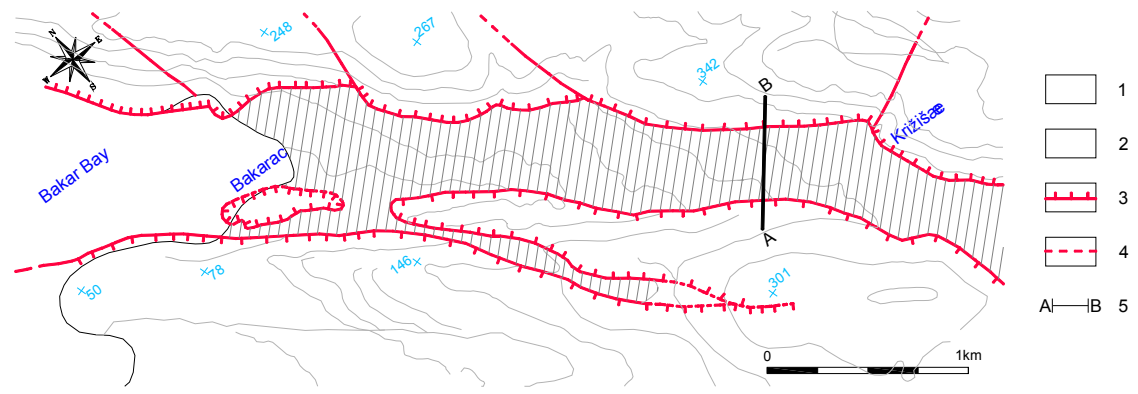

Figure 2: $\quad$ Simplified geological map of studied area: 1-upper Cretaceous and Paleogene limestones, 2-Paleogene siliciclastic rocks (flysch) mostly covered by Quaternary sediments, 3-traces of reverse faults, 4-traces of strike-slip faults, 5-trace of geological cross-section (see Fig. 3, according to [16].

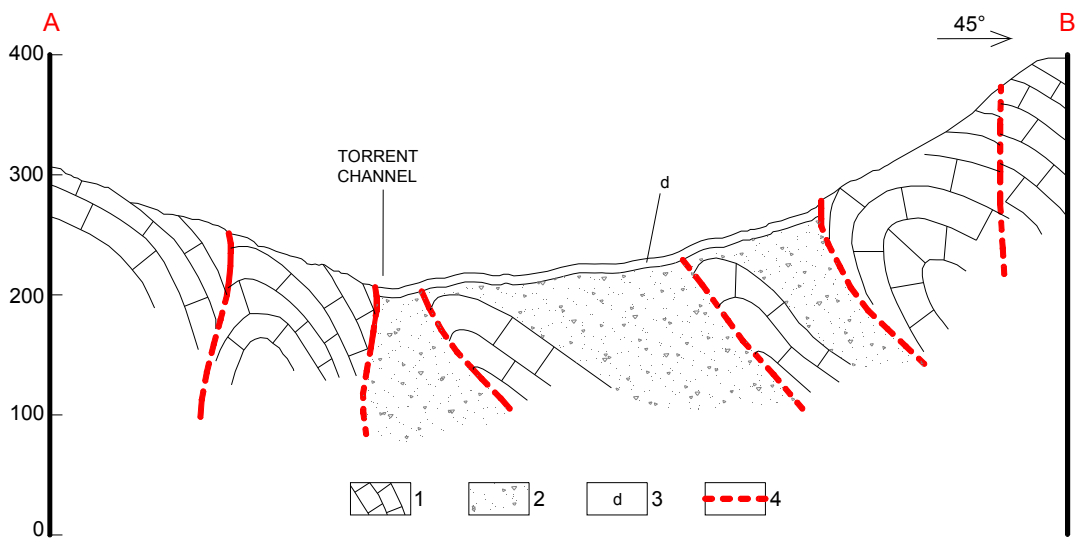

Figure 3: Geological cross-section of studied area: 1-upper cretaceous and Paleogene limestones, 2-Paleogene siliciclastic rocks (flysch), 3 -slope deposits 4-faults, according to [16].

Unlike limestone rock on the top of the slope, flysch rock mass is almost completely covered by weathered material, slope formation and talus deposits. During the morphogenesis processes, the limestone rock mass was repeatedly 
faulted and fractured. Such tectonic movements and weathering processes enabled separation of the limestone blocks and their gravitational sliding on the flysch bedrock, disintegration of the rock mass, as well as the accumulation of talus deposits at the foot of the rock cliffs.

Siliciclastic or flysch rock mass is characterized by great lithological heterogeneity, because of the frequent vertical and lateral alternation of different lithological sequences. Microscopic petrological analysis of the bedrock has shown the presence of silty marl, siltstones, as well as fine grained sandstones [16]. Unlike the limestones, the flysch rock mass is more prone to weathering, resulting with a clayey weathering zone over the flysch bedrock. Over time, coarse grained fragments, originating from the rock falls, were mixed with clay from the weathered flysch zone and slope deposits several metres thick were formed (Fig. 3).

\section{Landslides susceptibility analyses in investigated area}

The number of factors included in the landslide hazard analyses could significantly vary in different approaches. Some assessments are based on lithology and slope data [18-20], and others use larger number of factors where each factor is quantified and its influence on landslide appearance is verified [21, 22]. For the analysis of landslide susceptibility in the investigated part of the Vinodol Valley, all available data gained from multiple geological and geotechnical investigation works were analysed. Different methods were combined during the research and data gathering: surface research based on engineering-geological mapping of terrain, field investigations and geophysical measurements results, ortho rectified photos and aerial photos of the area, and GIS analyses. Detailed analyses of possible instabilities and landslide hazard identification were directed to the flysch area in the central to lower parts of the Valley (Fig. 3). Based on experience on similar terrains it was concluded that the main triggering factors on flysch slopes in studied area were intensive rainfalls which anticipated sliding [23], but further analyses concerning the back period and time of landslide occurrence were not performed in this analyses.

\subsection{Instabilities in the area}

Large number of different instability phenomena was present in the area of dominant geomorphological unit Rječina River Valley - Sučka Draga Valley Bakar Bay - Vinodol Valley, during the last 30 years [24, 25]. Movement velocities of $1 \mathrm{~cm} /$ year that mach soil creep and landslides in their initial stage, attended with terrain erosion were registered. The fastest movements occurred episodically, as an answer to the change in geological and hydrogeological environment conditions. In the phase of landslide identification it was concluded that appearance of rock falls from limestone blocks in the area is possible, but not so threatening.

Slopes affected by sliding have distinctive water infiltration anisotropy. Groundwater flow in cohesionless talus material is very rapid, in contrast to 
cohesive talus material where water flow is slow. Hypodermic groundwater can be accumulated locally in clayey and silty slope material in the weathering zones. This water originates either from a direct infiltration of precipitation or from the karst aquifer on the top of the slope. Surface flowing usually happens in the cover, that is, on the contact with impermeable flysch bedrock. Groundwater is discharged by the main torrent channel [26] (Fig. 4). During the rainy periods, the mesh of water flows appears due to the low permeability flysch bedrock layers. Therefore erosion is sporadically expressed. The characteristic of the flysch bedrock in the whole Vinodol Valley is the exchange of the area where the cover has the function of erosion protection and bare parts where the basic rocks are attacked by erosion [24]. Cultivated areas have the terrace shapes with mesh of drainage canals to reduce the harmful effect of erosion and to improve the stability of the slopes.

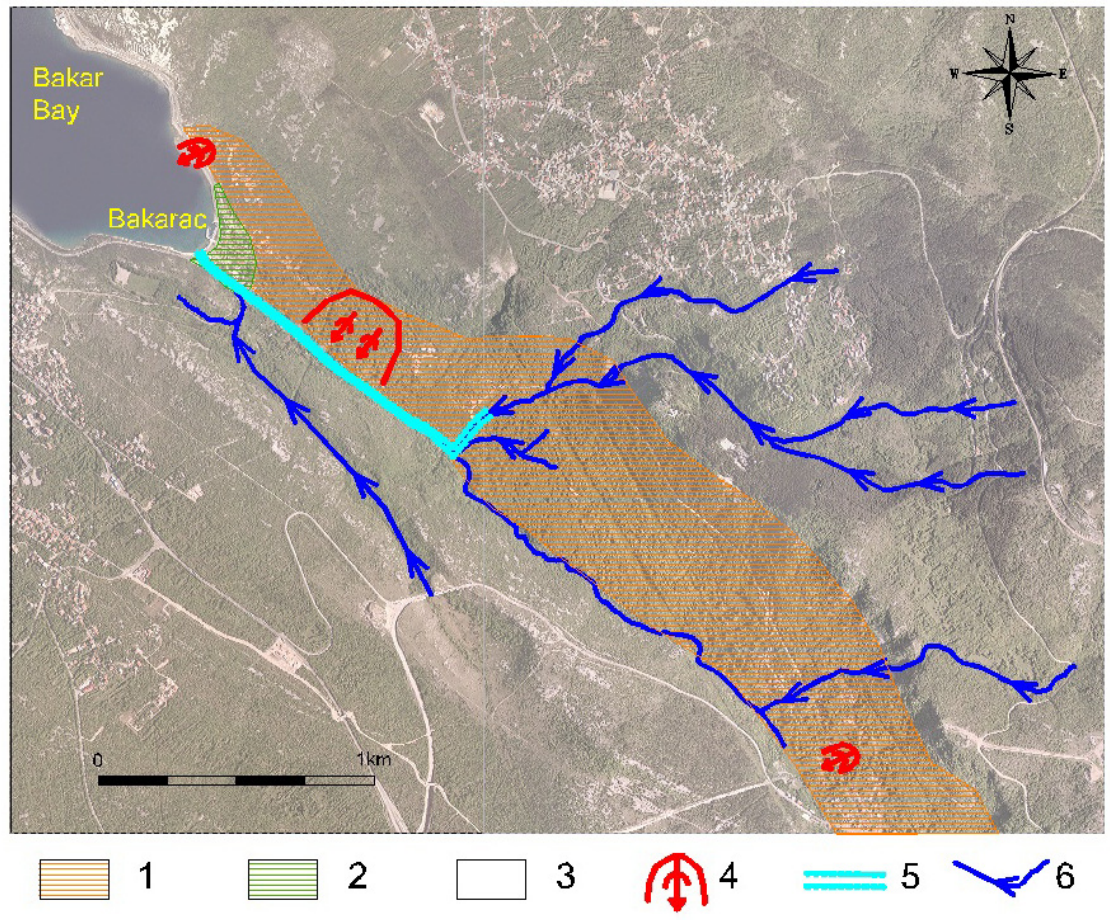

Figure 4: Ortho-rectified aerial photo of the area: 1-potentially unstable flysch slope, 2-prolluvium sediments, 3-upper Cretaceous and Paleogene limestones, 4-zone of active and dormant landslides, 5-regulated torrent channel; 6-natural torrent channel.

Measurements in piezometers and wells enabled establishment of the groundwater level in some parts of the area. As the flysch bedrock is practically impermeable, water table has the surface compatible with the surface of the contact of the cover and the flysch bedrock. Consequently, from the flysch 
bedrock slope map, and the individual data about the groundwater level, it is possible to make the water table surface by interpolation and extrapolation, and to make the groundwater flow directions. That makes the analysis of the hydrodynamic forces possible. Knowing the direction of hydrodynamic forces is crucial for determining the possible directions of slope masses movements.
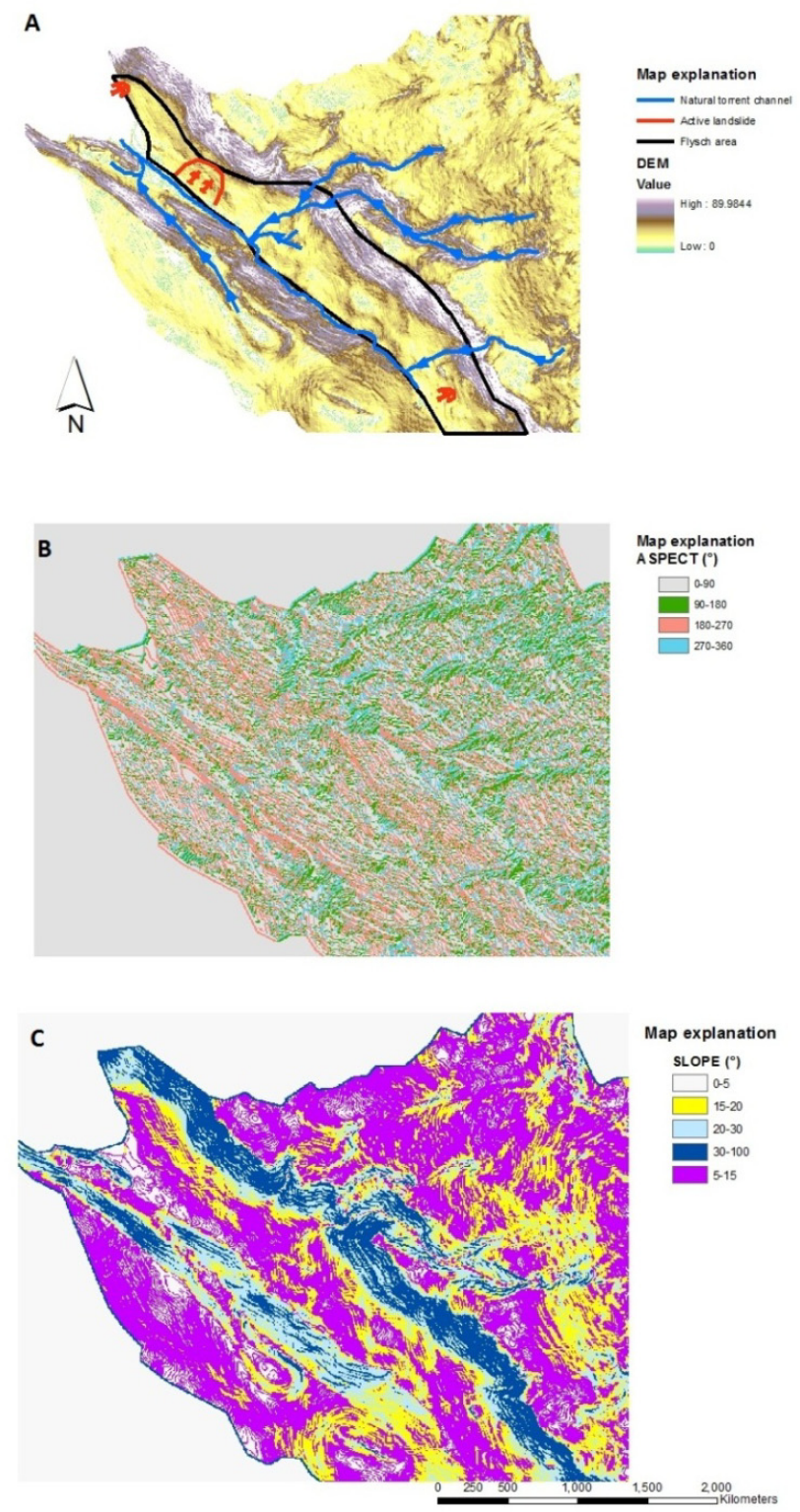

Figure 5: Zoning in the investigated area: A- Digital elevation map; B- Slope angle map; C-Slope orientation map. 


\subsection{Results of the analyses}

Landslide susceptibility assessment was made based on analysis of slopes of the cover, geological fabric of slope deposits and hydrogeological conditions inside the framework of qualitative analyses, based on the experience and knowledge about the past and present sliding and geomorphological conditions which anticipated these processes. GIS was used to gather, store, process and present the landslides data. Digital elevation model (DEM) with resolution $5 \times 5 \mathrm{~m}$ was made using geodetic data about points, polylines and polygons. Information about specific geomorphological, lithological, structural and hydrological attributes was joined to each pixel. Slope angle and slope orientation map were derived out of DEM (Fig. 5) and used in the analysis.

The basic thesis in landslide susceptibility assessment was that similar conditions which led to sliding in the past, will lead to similar movements of the slope mass in the future $[23,26]$.

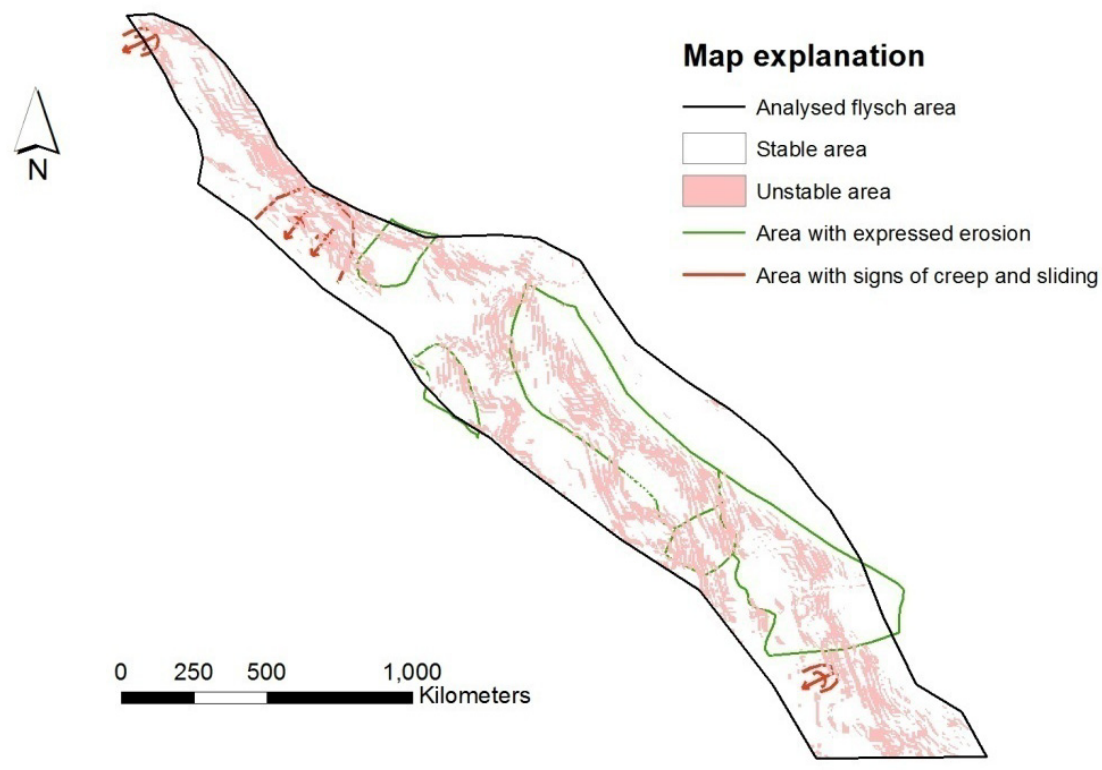

Figure 6: $\quad$ Landslide susceptibility map in flysch area.

Landslide susceptibility map (Fig. 6) was made by analyses of unfavourable conditions in the investigated area. Stable area was established in the flysch zone with relatively low slopes, usually between 15 and 20\%. Regardless of the cover thickness and relatively high groundwater level, movements in this area are not possible, because the hydraulic gradient and hydrodynamic forces are very low. Area with expressed erosion is found at relatively stiff slopes and very thin or with no cover. Thick layers of weathered flysch rock mass, with some or no vegetation, and with occasional surface flows were established in these parts. 
Potentially unstable area has slopes between 15 and $37 \%$, and the cover is usually $>3 \mathrm{~m}$ thick. This is as well a characteristic of existing landslides in the area $[26,27]$. Terrains with bedrock slopes between 20 and 35\%, where landslide instabilities occur, were assigned as unstable area.

\section{Conclusions}

In the area of dominant geomorphological unit Rječina River Valley - Suščka Draga Valley - Bakar Bay - Vinodol Valley, many different phenomena of instability were found on flysch slopes in the past 30 years. Landslide susceptibility assessment was performed in one small part of this unit: northwestern part of the Vinodol Valley between the Bakar Bay and the neck near the Križišće settlement, based on analysis of the slopes, geological setting and geotechnical properties of the deposits in the geological profile and hydrogeological conditions. Slopes and the bottom of the valleys are built in flysch rock mass complex, consisting mainly of silty marl, siltstones and fine grained sandstones confined by fractured and karstified limestone rock mass.

Performed analyses divided the analysed flysch area into four classes of landslide susceptibility (Fig. 6): stable area, area with expressed erosion, potentially unstable area and unstable area with signs of creep and sliding. The results were compared with $2 \mathrm{D}$ stability analysis performed for single locations during the remediation works design. The comparison has shown a relatively good analogy with certain differences in transition areas. Contribution of this kind of assessment in flysch slopes gains the importance when applied to larger areas and definitely in combination with stability analysis performed on individual locations.

\section{References}

[1] Varnes, D.J. \& IAEG Commission on Landslides and other MassMovements, Landslide hazard zonation: a review of principles and practice. The UNESCO Press. Paris, p.63, 1984.

[2] Carrara, A. and Guzzetti, F. (eds.), Geographical Information Systems in Assessing Natural Hazards. Kulwer Academic Publishers. Dordrecht, 1995.

[3] Brabb, E.E., Innovative approaches to landslide hazard mapping. Proc. of the 4th Int. Symp. on Landslides: Toronto, 1, pp. 307-324, 1984.

[4] Guzzetti, F., Reichenbach, P., Cardinali, M., Galli, M. and Ardizzone, F., Landslide hazard assessment in the Staffora basin, northern Italian Apennines. Geomorphology, 2005.

[5] Aleotti, P. and Chowdhury, R., Landslide Hazard Assessment: Summary Review and New Perspectives - Bulletin of Engineering Geology and Environment 58, pp. 21-44, 1999.

[6] Fell, R., Corominas, J., Bonnard, C., Cascini, L., Leroi, E. and Savage, W.Z., Guidelines for landslide susceptibility, hazard and risk zoning for land use planning, Engineering Geology 102: pp. 85-98, 2008. 
[7] Benac, Č., Dugonjić, S., Arbanas, Ž., Oštrić, M. and Jurak, V., The Origin Of Instability Phenomena Along The Karst-Flysch Contacts. ISRM International Symposium Rock Engineering in Difficult Ground Conditions: Soft Rock and Karst, October, 2009, Cavtat (Vrkljan, I., ed.). CRC Press, Boca Raton-London-New York- Leiden, pp. 757-761, 2009.

[8] Hanock, P.L. and Skinner, B. J., (eds.). The Oxford Companion to the Earth Oxford University Press, pp. 1174, 2000.

[9] Attewell, P.B. and Farmer, I.W., Principles of Engineering Geology, New York, John Wiley \& Sons, p 1045, 1979.

[10] ISRM, Quantitative description of discontinuities in rock masses. International Journal of Rock Mechanics and Mining Sciences \& Geomechanical Abstract, 15, pp. 89-97, 1978.

[11] Marinčić, S., Eocene flysch of Adriatic zone. Geološki vjesnik 34, pp. 2738, 1981, (in Croatian).

[12] Marinčić, S. and Matičec, D., Tectonics and kinematics of deformations on example of Istria. Geološki vjesnik 44, pp. 257-268, 1991, (in Croatian).

[13] Korbar, T., Orogenic evolution of the External Dinarides in the NE Adriatic region: a model constrained by tectonostratigraphy of Upper Cretaceous to Paleogene carbonates, Earth-Science Reviews 96, pp. 296-312, 2009:

[14] Velić, I. and Vlahović, I., Basic geological map of republic of Croatia 1:300.000. Hrvatski geloški institut, Zagreb. (in Croatian), 2009:

[15] Blašković, I., Tectonics of Part of the Vinodol Valley within the Model of the Continental Crust Subduction. Geologia Croatica 52 (2), pp. 153-189, 1999.

[16] Magdalenić, A., Jurak, V. and Benac, Č., Engineering geological Problems of Harbour building in the Southwestern part of the Bakar Bay. Pomorski zbornik, 30, pp. 633-654, Rijeka, 1992, (in Croatian).

[17] Benac, Č., Engineering-geological Characteristics of the Coastal and Submarine zone of the Rijeka Bay, PhD Thesis, Faculty of Mining, Geology and Petroleum Engineering, University of Zagreb, 1994, (in Croatian).

[18] Brabb, E. E., Pampeyan, E.H. and Bonilla, M.G., Landslide susceptibility in San Mateo Country, California. US Geological Survey, Miscellaneous Field Studies Map MF-360, 1972.

[19] Blanc, R.P. and Cleveland, G.B., Natural Slope Stability as Related Geology, San Clemente Area, Orange and San Diego Counties, California. (California Division of Mines and Geology Special Report, 98), p 19, 1968.

[20] Nilsen, T.H., Wright, R.H., Vlasic, T. C. and Spangle, W., Relative Slope stability and Land-use planning in the San Francisco Bay Region, California. U.S. Geol. Surv. Professional Paper, p 944, 1979.

[21] Stevenson, P.C., An Empirical Method for the Evaluation of relative Landslide Risk. Bulletin IAEG, 16, pp. 69-72, 1977.

[22] Meneroud, J.P. and Calvino, A., Zones exposées à des risques liés aux mouvements du sol et du sous-sol à 1:25.000, région de la Moyenne Vesubie (Alpes-Maritimes) -Orléans. Bureau de Recherches Géologiques et miniéres, p 11, 1976. 
[23] Dugonjić Jovančević, S., Arbanas, Ž., Recent landslides on the Istrian Peninsula, Croatia. Natural Hazards, Journal of the International Society for the Prevention and Mitigation of Natural Hazards, Vol.62, 3, pp. 13231338, 2012.

[24] Benac, Č., Jurak, V., Oštrić, M., Holjević, D. and Petrović, G., Appearance of exceeded erosion in the Salt creek area (Vinodol Valley). In: Velić I, Vlahović I, Biondić R (eds) Abstract book of 3rd Croatian geological congress. Croatian Geological Institute, Zagreb, pp. 173-174, 2005.

[25] Arbanas, Ž., Benac, Č., Andrić, M. and Jardas, B., Geotechnical Properties of Flysch on the Adriatic Motorway from orehovica to St Kuzam. Saopćenja savjetovanja Geotehnika prometnih građevina-Novigrad, Vol.1, Zagreb, pp. 181-190, 1994, (in Croatian).

[26] Dugonjić, S., Arbanas, Ž. and Benac, Č., Assessment of landslide hazard on flysch slopes. In: Proceedings of the 5th Conference of Slovenian Geotechnical Society, Nova Gorica, pp. 263-272, 2008.

[27] Arbanas, Ž. and Dugonjić, S., Landslide risk increasing caused by highway construction, Proc. of the Interpraevent 2010, Su-Chin Chen (ed.), Taipei: International Research Society INTERPRAEVENT, pp. 333-343, 2010. 